\title{
Peran Gender Dalam Media
}

\author{
Nurina Orta Darmawati dan Putri Dwitasari \\ Departemen Desain Produk Industri, Fakultas Arsitektur Desain dan Perencanaan, \\ Institut Teknologi Sepuluh Nopember, \\ email: nurinaorta@gmail.com
}

\begin{abstract}
Abstrak - Fenomena gender yang terjadi dalam masyarakat adalah budaya patriarki yang menempatkan perempuan dalam posisi yang subordinat, begitu pun dalam sebuah kajian budaya dan media massa. Media dalam konteks ini lebih menyoroti mengenai televisi itu sendiri yang banyak berperan dalam melalui pesan visual yang menjadi kelebihannya dan sangat mempengaruhi konstruksi masyarakat mengenai suatu hal yang sebelumnya mereka pikirkan.Perempuan memang selalu dicitrakan sebagai manusia yang selalu mendominasi wilayah domestik, seiring dengan trend pertelevisian, wilayah tersebut dapat digantikan perannya oleh laki-laki begitu juga sebaliknya. Wacana gender yang terus mengemuka dewasa ini rupanya menjadi titik tolak dari pola pemikiran akan adanya kesenjangan peran laki-laki dan perempuan. Peran laki-laki atau perempuan itu bisa dipertukarkan dan berubah dari waktu ke waktu sesuai dengan kebutuhan.
\end{abstract}

Kata Kunci: gender, iklan, televisi, media

Abstract - A common phenomenon in the society is a patriarchial culture that put the woman in the subordinate position, even in cultural studies and media studies. Media in this context are putting the television in the spotlight, which plays a huge role in shaping certain images in people's mind, by delivering visual messages. A woman usually portrayed as a human that dominated the domestic chores and areas, but aligning with media and television trends, those domestic chores are replaced by a man. The gender studies in the society nowadays have become a turning point from old images of how women are the one responsible for doing household chores. Therefore, the gender role of man and woman are exchangeable depending on the timing and the needs.

Keywords: gender, advertisement, television, media

\section{PENDAHULUAN}

Salah satu yang menjadi sorotan menarik dalam kajian dari kelompok isu sosial ini adalah mengenai praktek gender dalam sebuah media televisi yang sedang mencari keproporsionalitasan peran antara laki-laki dengan perempuan. Dalam pembahasan presentasinya, kelompok ini mengemukakan tentang terjadinya sebuah gender intermediate yakni pertukaran wilayah peran antara laki-laki dan perempuan pada media televise . Kemudian juga dibahas mengenai tiga jenis gender yang mengisi layar pertelevisian di Indonesia, yakni feminin, maskulin dan netral, dimana yang mereka sebut netral merupakan kelompok seseorang yang berada dalam posisi laki-laki namun feminin dan perempuan namun maskulin [1]. Saat ini gender telah menjadi wacana sosial yang mempersepsikan berbagai manifestasi peran laki-laki dan perempuan dalam menata hubungan sosialnya [2]. Penelitian ini akan membahas mengenai pertukaran peran gender yang banyak terjadi di masyarakat.

Disisi lain, dalam beberapa tahun ini, tayangan televisi juga banyak sekali memunculkan berbagai acara yang dikhususkan untuk wanita namun dengan dominasi pria sebagai pelaku utama. Hal ini merupakan trend baru dunia pertelevisian, seperti contohnya menampilkan para chef pria dalam sebuah acara memasak.Selain chef pria, presenter pria yang membawakan acara genre wanitapun mulai bermunculan.Seperti Bondan Winarno yang membawakan acara wisata kuliner.Secara tradisional, memasak merupakan dunia perempuan.Hal ini merupakan konsep budaya yang bias gender. Kemudian sederet nama artis pria yang menbawakan acara infotainment dan talk show kecantikan yang notabene untuk wanita. Yang menarik, berbeda dengan pria yang terjun di dunia mode atau kecantikan, yang cenderung bersifat kemayu, pria-pria tersebut berpenampilan gagah sebagaimana menunjukkan maskulinitas seorang pria.Pria-pria tersebut juga merupakan komoditas hiburan yang mulai diterima sebagai salah satu hiburan yang menyenangkan bagi para wanita.

Dalam perspektif gender, maskulin maupun feminin sebenarnya merupakan pilihan [3]. Artinya pria dan wanita dapat secara bebas memilih penampilannya sendiri sesuai dengan yang disukainya.Tidak ada kewajiban bahwa pria harus menampilkan dirinya sebagai sosok maskulin dan feminin bagi perempuan.Sifat-sifat sebagaimana tersebut diatas dapat dipertukarkan satu dengan yang lainnya.Pria dapat berpenampilan feminin sementara wanita dapat memilih penampilan sebagai sosok yang maskulin.

\section{METODE PENELITIAN}

Penelitian ini menggunakan analisis wacana dimana wacana diartikan sebagai domain umum dari semua pernyataan, yaitu semua ujaran atau teks yang mempunyai makna dan mempunyai efek dalam dunia nyata.Misalnya perempuan nampak tegas dan rasional, sebaliknya laki-laki bisa emosional, ramah dan lemah lembut (dalam acara televisi di Trans TV). Perempuan bisa menjadi bos di kantor, pria pun tidak masalah bila harus mengasuh bayi, memandikan, dan mengganti popok. Memasak, mengepel lantai, dan aktivitas domestik lainnya. Hal tersebut yang kemudian ditangkap oleh stasiun televise untuk direpresentasikan dalam sebuah acara televisi. 

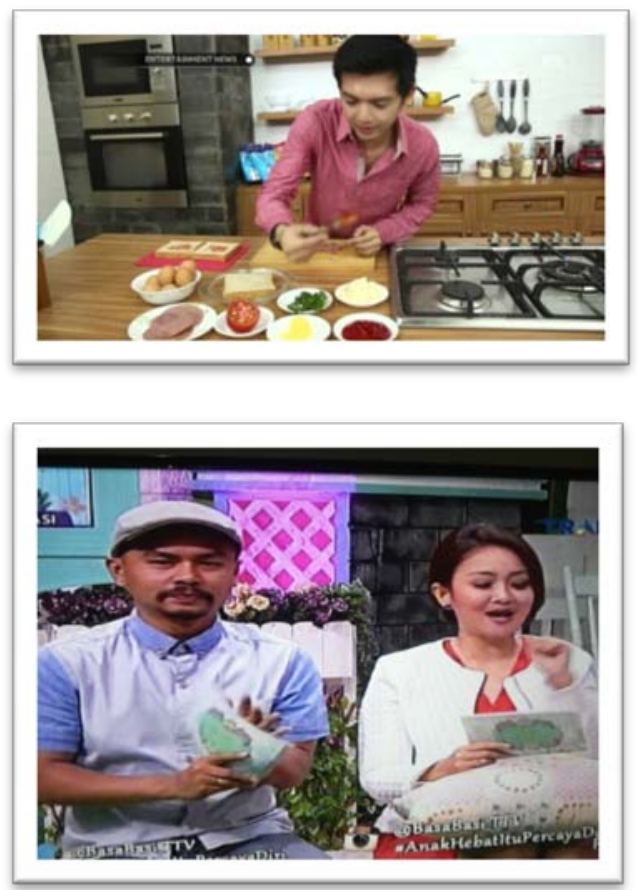

Gambar 1.Presenter pria dalam acara wanita

Gambar 1 menampilkan sosok laki-laki yakni Nicky Tirta yang dimunculkan sebagai sosok yang maskulin namun mengerjakan pekerjaan perempuan. Ditunjukkan bahwa perempuan menjadi seorang leader dalam sebuah acara dimana sosok Wendy (laki-laki) menjadi pendamping di acara wanita.

\section{HASIL DAN PEMBAHASAN}

\section{Gender dalam media televisi}

Membicarakan perempuan dalam hubungannya dengan lakilaki, perlu dipahami dua aspek pokok, sekaligus dilakukan pembedaan antara keduanya.Dua aspek tersebut adalah seks (jenis kelamin) dan gender.Pengertian seks sebagai jenis kelamin adalah pembedaan yang didasarkan pada fisik manusia.Pembedaan kedua adalah berdasar gender.Pembelajaran sosial tersebut menempatkan laki-laki dan perempuan dalam wilayah yang berbeda, sehingga dicitrakan dalam penampilan berbeda pula.Pria dicitrakan dalam sifat maskulin sementara perempuan dalam penampilan feminin.Pembelajaran sosial tersebut merupakan konstruksi sosial (social construction) yang secara terus menerus terjadi dalam kurun waktu yang sangat lama dan terjadi dalam semua bidang kehidupan.Karena memiliki otot yang lebih kuat, laki-laki menenganai pekerjaan fisik yang berat, sementara perempuan sebaliknya.

Gender pada dasarnya adalah pembagian peran serta tanggung jawab baik perempuan maupun laki-laki yang ditetapkan secara kultural maupun sosial. Gender sesungguhnya berkaitan erat dengan proses keyakinan bagaimana seharusnya perempuan dan laki-laki diharapkan untuk berfikir dan bertindak sesuai dengan ketentuan sosial dan budaya dimana mereka berada.

Stereotip perempuan menjadi wacana dalam sebuah acara rancangan televisi, menempatkan stereotip itu dalam konteks sentral televisi.Perempuan harus tampil cantik secara fisik, mampu mengurus semua keperluan rumah tangga dan anggota keluarga, serta sebagai objek seksual. Hal-hal inilah yang terlihat dalam sebuah acara televisi, sebagai yang disebut dengan rekontruksi sosial, bahwa acara-acara tersebut hanya merekontruksi apa yang ada di sekitarnya, serta apa yang menjadi realitas sosial di masyarakat.

Perempuan itu memang seharusnya cantik, stereotip bahwa wanita harus cantik dalam sebuah tampilan di televisi ini telah direduksi dan dipahami secara lebih sederhana dengan bertubuh langsing, berkulit putih, halus, lembut, berambut indah, tinggi semampai [4]. Padahal pengertian cantik tidak hanya sebatas kecantikan lahiriah semata, memang pada awalnya orang memandang kecantikan lahiriah namun akhirnya juga akan menyentuh kecantikan batiniah. Hal inilah yang menyebabkan kaum perempuan menjadi sasaran empuk pertelevisian selama ini. Walaupun kenyataannya mereka hanya sebagai figur pelengkap dalam menarik massa (Gambar 2).
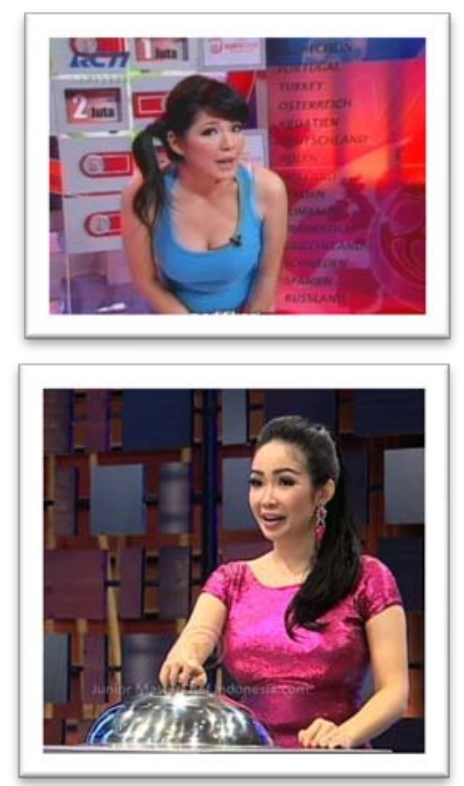

Gambar 2.Perempuan cantik (feminin) dalam sebuah acara televisi

Fenomena gender intermediate dalam media televisi

Di Indonesia saat ini, penampilan perempuan dalam media televisi tidak jauh dari konstruksi bias gender yang mirip dialami oleh mereka sendiri di kehidupan bermasyarakat.Mereka ditampilkan sebagai the other, disubordinasikan, dan masih di wilayah domestik.

Namun seiring dengan perkembangan pertelevisian di Negara kita, tak bisa dipungkiri bahwa semakin dewasa media televisi semakin menonjolkan adanya peran wanita di luar konstruksi umum tersebut yakni dalam acara pria untuk menarik minat pemirsanya [5]. Mereka ditampilkan tidak 
lagi sesuai dengan konstruksi umum tentang arti feminin : lemah lembut, lemah fisik, halus, pasif, rendah hati, dan sejenisnya; namun maskulin: rasional. Kuat, cerdas, dan tegas (Gambar 3).
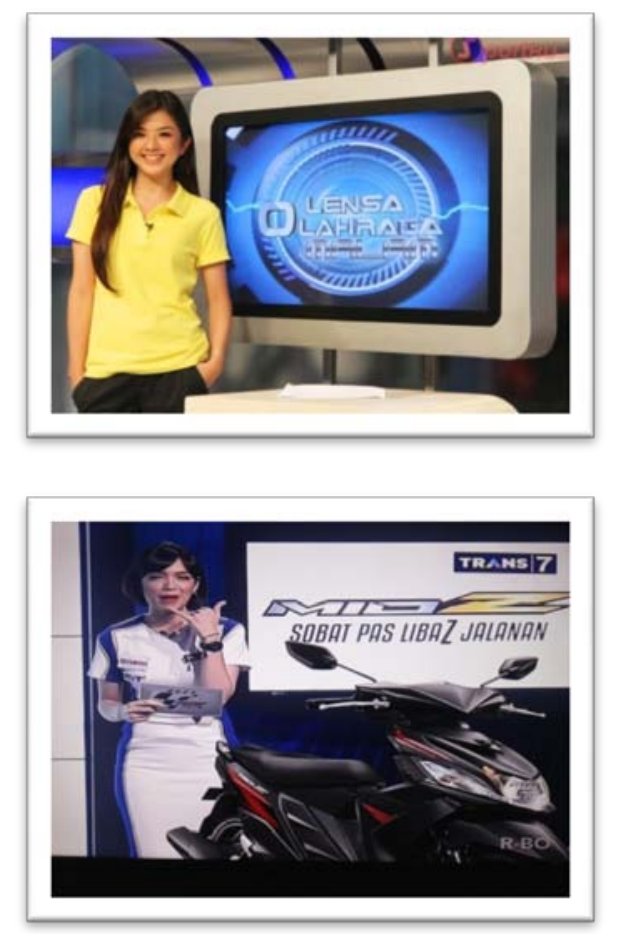

Gambar 3. Presenter wanita pada acara pria

Globalisasi informasi dan komunikasi memberi pengaruh pada pola pikir manusia yang berpengaruh juga pada tematema tampilan dalam media televisi. Sebagai contoh, presentasi kemunculan perempuan dalam acara yang dahulu seharusnya didominasi kaum pria semakin bertambah seperti dalam acara sepak bola, otomotif, talk show, quiz dll. Kemudian iklan yang bertema kesetaraan gender yang sedikit banyak membantu pembelajaran masyarakat akan nilai-nilai maskulinitas yang tidak hanya boleh dimiliki oleh laki-laki saja, dan acara lain yang ada pada media televisi. Pertukaran wilayah ini merupakan bagian dari penyamarataan gender yang belakangan ini menjadi perbincangan dalam media yang saat ini menjadi trend pertelevisian di Indonesia.

Dalam perspektif gender, maskulin maupun feminin sebenarnya merupakan pilihan.Artinya pria dan wanita dapat secara bebas memilih penampilannya sendiri sesuai dengan yang disukainya.Tidak ada kewajiban bahwa pria harus menampilkan dirinya sebagai sosok maskulin dan feminin bagi perempuan.Sifat-sifat sebagaimana tersebut diatas dapat dipertukarkan satu dengan yang lainnya.Pria dapat berpenampilan feminin sementara wanita dapat memilih penampilan sebagai sosok yang maskulin.

Tercatat beberapa artis perempuan yang pernah dan sedang membawakan acara genre olah raga di televisi yang seharusnya didominasi oleh laki-laki, yakni Di Metro TV : Frida Lidwina (Metrosport Corner, Dian Khrisna Mukti (Metro Sport), Anya Dwinof (F-1). Di TV One : Lenna
Tan ( Review Liga Inggris ), Tamara Geraldine ( Football ). Di Trans-7 : Riyani Djangkaru (Sport Tawa), Lucy Wiryono, Fiantika Ambadar (Sport 7 pagi ), Terry Putri, Hesty Purwadinata (Sport 7 Malam), Leony (Kuis EPL/Galeri Sepakbola Indonesia), Della (Kuis Moto GP ), Widya ( Lega Calcio/Moto GP ). Di ANTV : Sabrina Sagita Kono (Lensa Olahraga ). Di Global TV : Lala Priscilla ( Motortrax ), Pia Pramarani ( Global Sport Malam ).
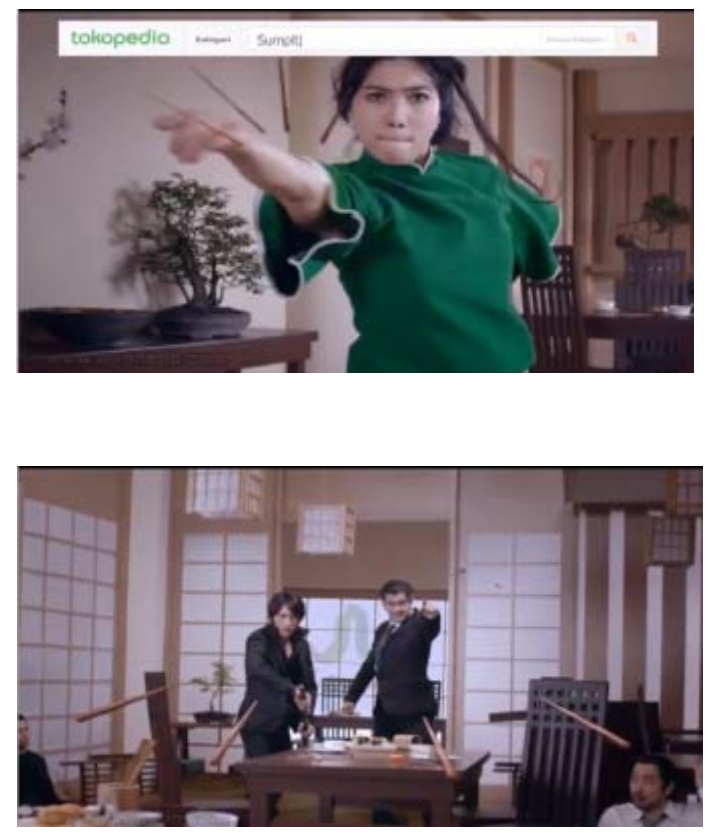

Gambar 4. Iklan televisi produk yang menggambarkan dominasi perempuanterhadap laki-laki dalam urusan kekuatan fisik.

Sedangkan dalam iklan, dewasa ini terkadang perempuan digambarkan dengan sifat-sifat maskulin.Mereka gesit, kuat, dan terkadang mampu melumpuhkan laki-laki.Misalnya pada iklan produk sabun mandi kecantikan LUX yang menampilkan tokoh Dian Sastro yang mampu menjungkirbalikkan laki-laki penggoda (Gambar 4).

Pesan dari iklan tersebut secara tersirat ditinjau dari perspektif gender hendak mengatakan bahwa kecantikan bukan berarti untuk dilecehkan.Disana ada nilai-nilai kehormatan yang harus dijaga dan kalau perlu dipertahankan dengan keras. Sekali lagi ini pembelajaran secara tersirat bagi semua pihak untuk tidak melihat kecantikan dan perempuan sebagai objek laki-laki namun mereka perlu untuk dihormati dan dihargai sama seperti lainnya meskipun secara tampilan visual sisi kecantikan perempuan dalam iklan ini yang lebih terekspos.

Meskipun demikian, bias gender sangat tampak dalam fenomena pertukaran wilayah ini.Perempuan dan segala stereotipnya dalam pandangan media televisi adalah tetap sebagai komoditas yang laku di jual.Media, sebagai bagian dari lingkaran produksi yang berorientasi pasar menyadari adanya nilai jual yang dimiliki perempuan, terutama sebagai pasar potensial [6]. Televisi memanfaatkan sex appeal wanita dengan sengaja agar menarik perhatian penonton.Perempuan tersebut sengaja diexpose dengan menggunakan pekaian yang minimalis untuk meningkatkan 
rating.Tanpa disadari, presenter wanita beserta seluruh tampilannya mempunyai daya pikat tertentu dalam menarik orang-orang dalam menikmati acara untuk pria (olah raga). Itulah sebabnya banyak perempuan yang direkrut untuk membawa acara untuk pria di layar kaca.

\section{Dampaknya terhadap masyarakat}

Dalam kehidupan masyarakat kapitalis, media televisi telah menjadi bagian hidup yang sulit dielakkan.Ia menyajikan gambaran tentang realitas, dan sekaligus mendifinisikan keinginan dan kemauan seseorang. Ia mendifiniskan apa itu gaya, apa itu selera, dan apa itu trend. Definisi-definisi ini bukan sebagai saran atau pendapat bagi konsumen, tapi sebagai tujuan untuk mempengaruhi.Definisi yang secara paksa disajikan pada kita semuanya itu datang secara tibatiba, lantas menebarkan pesonanya guna menyihir semua orang yang melihatya.

Sebenarnya penggambaran wanita yang dominan dan "kuat” kebanyakan justru menempatkan wanita itu sendiri sebagai objek olok-olok. Kekuatan yang diperlihatkan biasanya justru hal-hal yang hanya menampilkan “kekuatan” secara superfisial seperti ambisius, suka menang sendiri, sok-pintar, suka intrik.Hal ini tentu mereduksi konsep kesetaraan gender, diganti dengan skeptis yang dikonstruksikan oleh budaya patriarki.Begitu pula dengan hal yang terjadi dengan penggambaran pria yang melakukan kegiatan atau yang berkecimpung di bidang wanita.

Bisnis pertelevisian dirasakan sangat menguntungkan bagi sebagian masyarakat industri.Bagaimanapun juga media televisi tersebut mampu mendongkrak tingkat perekonomian, menciptakan lapangan kerja, serta membantu percepatan arus informasi baik komoditi produk, produk dan jasa, sampai pada hiburan yang dibutuhkan oleh masyarakat.Akan tetapi jika disimak lebih jauh, media televisi secara implisit mempunyai ideologi yang dicoba untuk ditanamkan dalam benak pemirsa, apalagi ideologi tersebut bersifat modernism, hedonism, atau bahkan imitasi keperilakuan. Kesemuanya tersebut akan membawa dampak dalam persepsi pemirsa, dan lambat laun akan berpengaruh terhadap kehidupan sosial.

\section{KESIMPULAN}

Meskipun pertukaran wilayah peran laki-laki dan perempuan dalam media televisi banyak ditunjukkan sebagai bagian dari penyetaraan gender, namun media tersebut masih memberi tempat bagi proses legitimasi bias gender, terutama dalam menampilkan representasi perempuan. Kecenderungan yang kemudian tampak dalam visualisasinya adalah menempatkan obyek-obyek pilihan yang diakui sebagai ikon yang dapat diposisikan menempati urutan atas daya tarik visualisasi representasi tayangan media televisi.

Perempuan lebih sering menjadi alternatif pilihan sebagai obyek yang dapat menciptakan daya tarik serta merefleksikan citra.Perempuan memang telah menjadi fenomena komoditas yang tak terelakkan dalam kancah komunikasi pertelevisian.Perempuan telah menjadi sarana legimitasi daya tarik terhadap aktualisasi nilai sebuah produk.Sebuah produk yang pada kenyataannya mempunyai fungsi yang general, telah dikomunikasikan tidak lagi bersifat fungsional tetapi sudah bergeser ke arah konsep gender.

Femininitas atau maskulinitas seringkali menjadi ajang manifestasi untuk membuat komoditi atau produk mempunyai nilai tertentu.Wacana perempuan dalam program televisi dapat dikritisi melalui cara pandang yang digunakan dalam menjadikan perempuan sebagai subyek, untuk kemudian dilihat interaksinya dalam konteks kekuasaan. Dunia show-biz yang menjadikan perempuan sebagai sumber lawakan misalnya, menunjukkan ketidakadilan gender dari struktur kekuasaan yang tidak seimbang. Penonton perempuan boleh jadi juga ikut menertawakan lawakan ini, karena juga ikut sebagai bagian dari nilai dominan dalam kekuasaan struktural.Hiburan semacam ini hanya menjadi replika dari konstruksi sosial yang bias gender.

Namun wacana gender yang terus mengemuka dewasa ini rupanya menjadi titik tolak dari pola pemikiran akan adanya kesenjangan peran laki-laki dan perempuan. Hal ini berpengaruh juga dalam media televisi sehingga tidak jarang saat ini tampilan televisi yang menggunakan sosok perempuan sebagai faktor yang dominan mulai bermunculan.Dalam iklan ini perempuan digambarkan cerdas, tegas, kuat secara fisik dan/atau mentalnya. Dengan kata lain, kekuatan fisik yang menjadi dasar dalam logika maskulinitas laki-laki menjadi tidak terbukti. Perempuan pun bisa maskulin dalam konteks gender.Dimana peran lakilaki atau perempuan itu bisa dipertukarkan dan berubah dari waktu ke waktu sesuai dengan kebutuhan.Misalnya perempuan nampak tegas dan rasional, sebaliknya laki-laki bisa emosional, ramah dan lemah lembut. Perempuan bisa menjadi bos di kantor, pria pun tidak masalah bila harus mengasuh bayi, memandikan, dan mengganti popok. Memasak, mengepel lantai, dan aktivitas domestik lainnya.

\section{DAFTAR PUSTAKA}

[1] Liestianingsih. 2002. Ideologi Gender dalam Iklan Kosmetik di Televisi. Surabaya: Pusat Penelitian Studi Wanita Lembaga Penelitian Universitas Airlangga.

[2] Prabasmoro, Aquarini. 2006. Kajian budaya feminis: tubuh, sastra, dan budaya pop. Yogyakarta: Jalasutra

[3] Liliweri, Alo. 1992. Dasar-Dasar Komunikasi Periklanan. Bandung: PT Citra Aditya Bakti.

[5] Prabasmoro, Aquarini. 2003. Becoming White: Representasi Ras, Kelas, Femininitas dan Globalitas dalam Iklan Sabun. Yogyakarta: Jalasutra

[6] Sobur, Alex. 2001. Analisis teks media: suatu pengantar untuk analisis wacana, analisis semiotik dan analisis framing. Bandung: Remaja Rosdakarya. 